Aleksander WINNICKI, Marta STAŃKOWSKA-RADZIUN and Krzysztof RADZIUN

Embryology

\title{
STRUCTURAL AND MECHANICAL CHANGES IN THE EGG MEMBRANES OF Salmo gairdneri Rich. DURING THE PERIOD OF HATCHING OF THE LARVAS
}

\author{
STRUKTURALNE I MECHANICZNE ZMIANY ZACHODZĄCE \\ W OSEONKACH JAJOWYCH PSTRĄGA TĘCZOWEGO (Salmo gairdneri Rich.) \\ W OKRESIE WYKLUWANIA SIE LARW
}

\author{
From Department of Ichthyology \\ Head: Prof. Dr. Eugeniusz Grabda
}

Structural and mechanical properties of the egg membranes of Salmogairdneri Rich. in the period of hatching were investigated.

Only local action of hatching enzyme upon the egg membrane and local decrease of its strength was observed. In the places, which were not under the action of the enzyme, egg shell keeps its structure unchanged as well as its great strength. The differences in the thickness of egg shells of the same female and even of the same egg were observed. No correlation between the thickness of the egg shell and its strength was found.

Mechanical properties of the egg membranes of Salmonid fishes are generally quite well known. It is also found that during the first hours and days after spawning they show rather great strength which is well kept during the whole period of development and falls down to zero only just before the moment of hatching ( $\mathrm{H}$ e i n, 1908; G r a y, 1932; H a y e s, 1942; Z o t i n, 1953a; Winnicki and D o m u rat, 1964). Such a decrease in the strength of egg membrane before hatching of larvas is caused by a special chemical substance, named by its discover "hatching enzyme" (W i n t r é $\mathrm{b}$ e $\mathrm{r} \mathrm{t}$ 1912). The enzyme is produced by special glands placed in the skin of the head, upon frontal parts of larva and upon the surface of yolk sack (W i n t ré b e r t, 1926; Bo u r di n, 1926a,b,c,d; I s hid a, 1944; Z ot in, 1953b; I g n a teva, 1956a, b; B a burina and Buz nik ov, 1957; B u z nik ov, 1957,1959).

Hatching enzyme causes the "digestion" of the inside part of the egg membrane (W i n t ré b e r t, 1912; H a y e s, 1942; M i l k m a n et al. 
1961), thus larva can easily liberate itself from the shell. H a y e s (1942) even introduces some kind of "thrill of terror", proving that hatching enzyme acts bilateraly: upon the shell and upon the larva itself, thus the result depends only upon the fact-which one of them digested quicker - the shell or the larva. Nota bene: neither Hayes, nor any one else have ever observed such, even partially "digested" embryo. It is believed that essential role on the process of hatching of larval fishes play the movements of the embryo. Got t w a l d and $\mathrm{N} \mathrm{a} \mathrm{gięc} \mathrm{(1967)} \mathrm{state,} \mathrm{that} \mathrm{as} \mathrm{the} \mathrm{result} \mathrm{of} \mathrm{violent} \mathrm{mo-}$ vements of the embryo the egg membrane is broken and thus embryo is released. It seems that the truth lies somewhere in the middle. Probably hatching enzyme acts upon interprotein bounds ( $F$ is h e $r, 1963$ ) and thus considerably weakens the shell. On the other hand, the embryo itself with the aid of violent movements "squeezes" out the enzyme directly upon the egg membrane (H a y e s, 1942).

The structure of the egg membranes is quite well studied. Generally, it is said that in the case of Salmonid fishes it is 30-40 $\mu$ thick with radialy situated canals (upon this character is based the name "zona radiata"), through which the exchange of substances with the environment takes place ( $\mathrm{R} \mathrm{u} \mathrm{n-}$ n s t r o m, 1920; Gr ay, 1932; Hay e s, 1942; S hanklin, 1959; A r m strong a. Child, 1965). Ka i g h n (1964) stated that those canals are only artefacts caused by the different refraction of the light in the substances filling them. The canals, as they are, do exist, but only in the ovocytular period, as it has been found by $M \ddot{u} l l$ e r and $S$ t e r b a (1963) by means of the electron microscope.

Although, there is rather abundant literature concerning egg membranes, very little is reported on the structural and mechanical properties of the egg shell in the moment of hatching, that is in the moment which is critical for the organism - since it is connected with violent change of the conditions. Such a lack is probably caused by the fact that during the hatching, in the eggs deriving even from the same female, can be observed enormeus differences much greater than any time before, such as relating to the manners of leaving the egg shells by the embryos and toits final destruction at the time of hatching.

The study of the morphological properties of egg membranes and the resulting changes in mechanical properties may be very significant. Some previous observations of several authors showed, that thicknessand strength of the egg membrane during the period of hatching is not always equal upon its whole area. The present work is a trial for explanation those morpho-functional changes and theirindependence in the egg shell during the hatching of larval fishes.

\section{MATERIAL AND METHODS}

Experiments were carried out during the spring of 1966 and 1967 at the Department of Fish Physiology of the Agricultural College in Olsztyn. 
The eggs of rainbow trout were derived from the River Biological Station of the Institute of Inland Fisheries at Gdańsk They were brought in Dewar flasks to our laboratory right after the formation of eye spots and incubated to the moment of hatching.

At about $60 \mathrm{D}^{\circ}$ before hatching, eggs were measured and their average strength was investigated. After $30 \mathrm{D}^{\circ}$ (that is also $30 \mathrm{D}^{\circ}$ before the theoretical moment of hatching) all experiments were started. All eggs were measured (three diameters: the shortest one, the longest and the height of an egg) and theirstrength on mechanical pressure was examined. The shells were fixed for histological investigations.

Diameter measurements of eggswere made by means of the measurement microscope up to within 0,01 mm.

The strength of egg shells (strength of the whole egg on mechanical pressure) was measured by the method of Schäperclaus (1940) and modified by authors

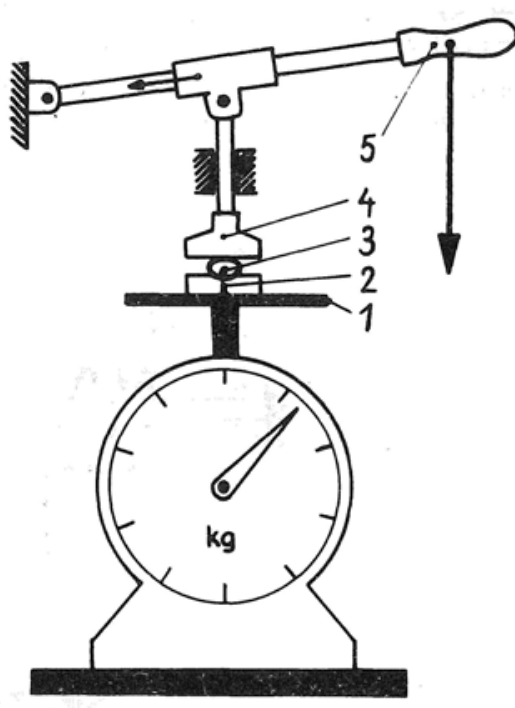

Fig.1.Apparatus for measuring of egg strength. 1 - scale of a spring balance; 2 - plexiglass saucer; 3 - egg; 4 - plastic disk; 5 - lever (Fig.1) in a following way: a special plexiglass saucer (2) with a hollow in the middle for the egg (3) was placed on the subject scale of a spring balance (1); a plastic disk (4) was lowered on the egg and then pushed with the hand (5) until egg was broken.

The egg membranes after breaking were washed in a solution $(0,6 \mathrm{~g} \mathrm{NaCl}$, $0,5 \mathrm{ml}$ of glacial acetic acid, $100 \mathrm{ml}$ of distilled water), fixed in $4 \%$ formalin, dehydrated in alcohol and finally embedded in paraffin. Cut sections (perpendiculary to the surface of an egg) $8 \mu$ thick were stained with hematoxylin and eosine.

The thickness of each egg shell was measured (in about 15 points). $20 \%$ of all measurements were taken from the brokenplaces of eggs. Thickness measurements were made by means of the microscope up to within $0,5 \mu$.

Apart from the above, we alsoinvestigated the egg shells (or rather their remnants), from which fishes already hatched, and eggs which showed "nought" strength. Histological method was the same. The strength of such shells was measured according to the modified method of $\mathrm{Z} \circ \mathrm{tin}$ (1953b), as it is illustrated on figure 2 . The shell (m) was placed upon slightly widen and grinded end of vertically standing tube (p); the external diameter of the tube was $4 \mathrm{~mm}$, internal $-2,5 \mathrm{~mm}$. The sides of tested shell were bonded with a thread. Metal bar (s) with the rounded end, $1 \mathrm{~mm}$ in diameter was lowered on the shell. The bar was connected to the moving arm of the lever $(g)$, which was fixed at the tripod axis (a) and balanced with a bob (w). At the end of 
laboring arm of the lever, a scale, shapedlike a flass vessel (b) was hung. From the vessel ( $\mathrm{v}$ ) standing just next, water was dropped into the scale until shell was broken. That amount of water was the measure of strength of the membrane (the length of arms was considered).

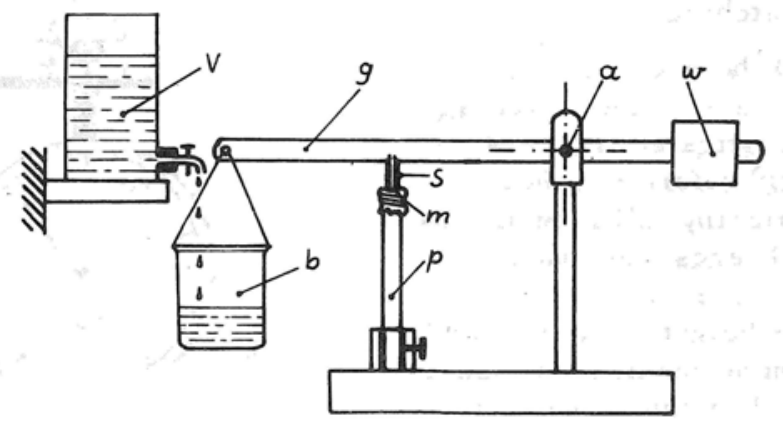

Fig.2. Apparatus for measuring of strength of the egg membranes after the hatching of larvas (scheme). a - axis; b - glass vessel; $\mathrm{g}$ - lever, m - membrane; $\mathrm{p}$ - glass tube; s - metal bar; $\mathrm{v}$-vessel with the water; w - bob

\section{RESULTS}

Data concerning the thickness of egg membranes during the period of hatching of larval fishes are given in Table 1.

T a b l e 1

The differences in the thickness of egg shells of Salmo gairdneri

\begin{tabular}{|c|l|l|l|l|l|c|}
\hline \multirow{2}{*}{\multicolumn{2}{|c|}{ Material }} & \multicolumn{2}{c|}{ The thickness of egg shell } & \multicolumn{2}{c|}{ The difference } \\
\cline { 2 - 7 } & minimal & maximal & average & in mm & in \% \\
\hline \multirow{2}{*}{$\begin{array}{c}\text { on } 50 \\
\text { eggs }\end{array}$} & \begin{tabular}{l} 
average value \\
\cline { 2 - 7 }
\end{tabular} & 27.41 & 46.60 & 35.95 & 19.20 & 70.00 \\
\hline \multirow{2}{*}{$\begin{array}{c}\text { on one } \\
\text { egg }\end{array}$} & $\begin{array}{l}\text { infividual } \\
\text { differences }\end{array}$ & 21.25 & 56.25 & - & 35.00 & 164.00 \\
\cline { 2 - 7 } & max.differences & 21.25 & 38.75 & 32.99 & 17.50 & 82.00 \\
\hline
\end{tabular}

Although the tested material was rather homogenous (the eggs were taken from the same female), the table shows a great differences in the thickness 
of egg shells. The differences could be divided into two groups : the differences in the thickness of the same egg shell, and of shells of different eggs.

From the data in Table 1 it follows, that a definite thickness of egg shell of the rainbow trout is quite out of question. Individual differences are so great, that in extreme cases the maximal thickness is $164 \%$ of the minimal. In numerical values, the thickest shell was $35 \mu$ more thick than the thinest one with the average thickness of $35 \mu$, which gives the difference (in plus, or in minus) of about $50 \%$.

Simultaneously, from this Table it follows, that the shell of the same egg does not have the equal thickness on its whole area. Minimal differences in the thickness of one egg membrane are greater than 8\%; in extreme cases even 10 times (82\%) greater. The imposition of the differences in the thickness of the membrane of one egg and of individual eggs, give such enormous differences between maximal and minimal values.

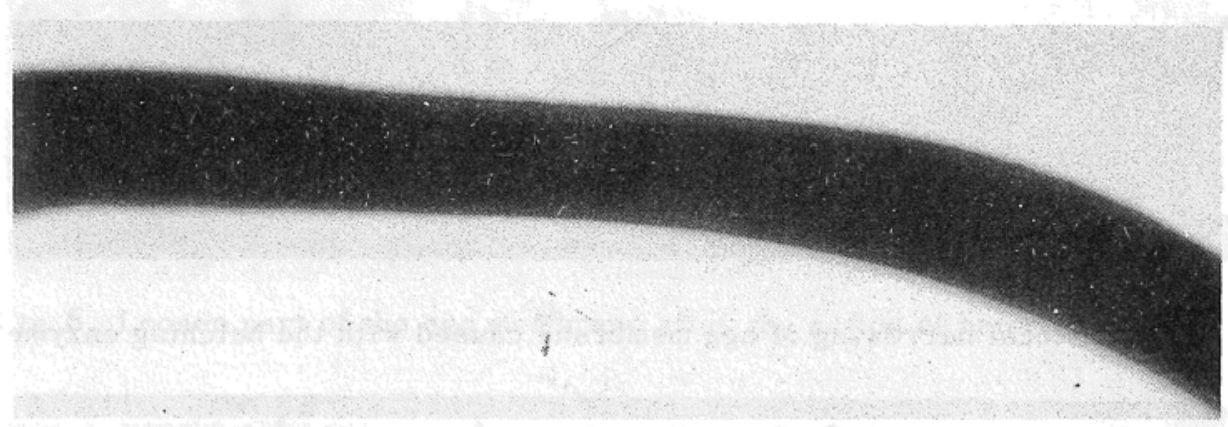

Fig.3. Egg membrane of Salmo gairdneri (the narrowing)

Fig. 3 shows a cross-section of the egg membrane with visible narrowing in the middle. Such narrowings are not frequent and rather rarely occur in the egg shells. Generally, the shells grow thinner gradually, so the process is almost invisible and only measurements of many sections of the egg shell can show the differences in the thickness. Such narrowings and thickening of the egg membrane are seemed to be the normal thing and has nothing to do with the hatching, because they occur a long time before hatching, in the period, when egg membrane still has very great strength.

An interesting fact could be observed during the time, when a membrane strength of the eggs is zero or near zero. Then could be seen a local narrowings of the membrane, but they are of completely different character than described above (Fig.4). The surface of the shell remains intact, but its lower parts seem to be partially digested or loosen (Fig.5 and 6). The egg shell breaks exactly in those places where it seems to be partially destroyed from the inside (Fig.7). It should be stated though, that breaking of the egg membrane by mechanical pressure before hatching, when it still has its great strength, very rarely takes place in the thinnest parts. Generally in such conditions, the shell breaks in its thicker places (Fig.8). Moreover, the thickness measurements of the egg membrane in the breaking places showed, that in those places it is about 7,8\% (in extreme cases even 210,4\%) thicker than the average thickness. On the other hand, in the period just before 


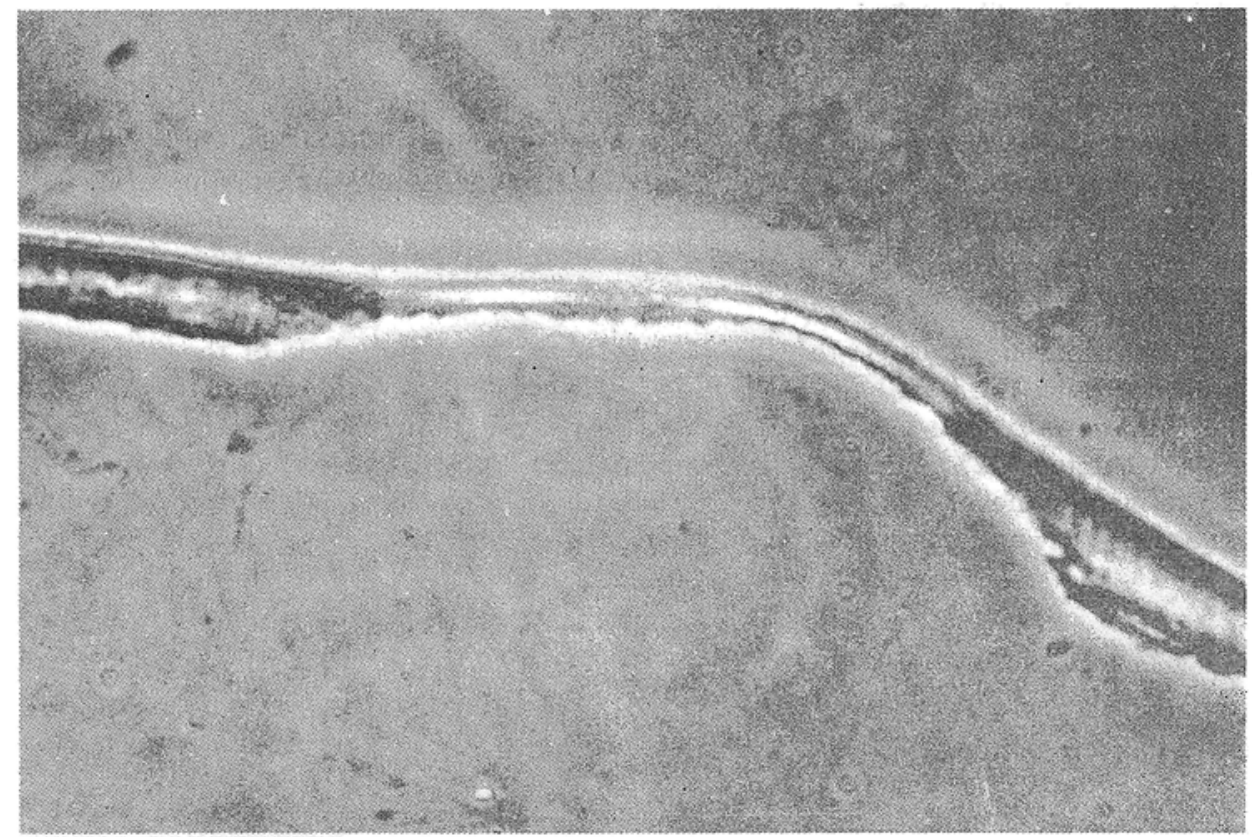

Fig.4. Local narrowing of egg membrane caused with the hatching enzyme

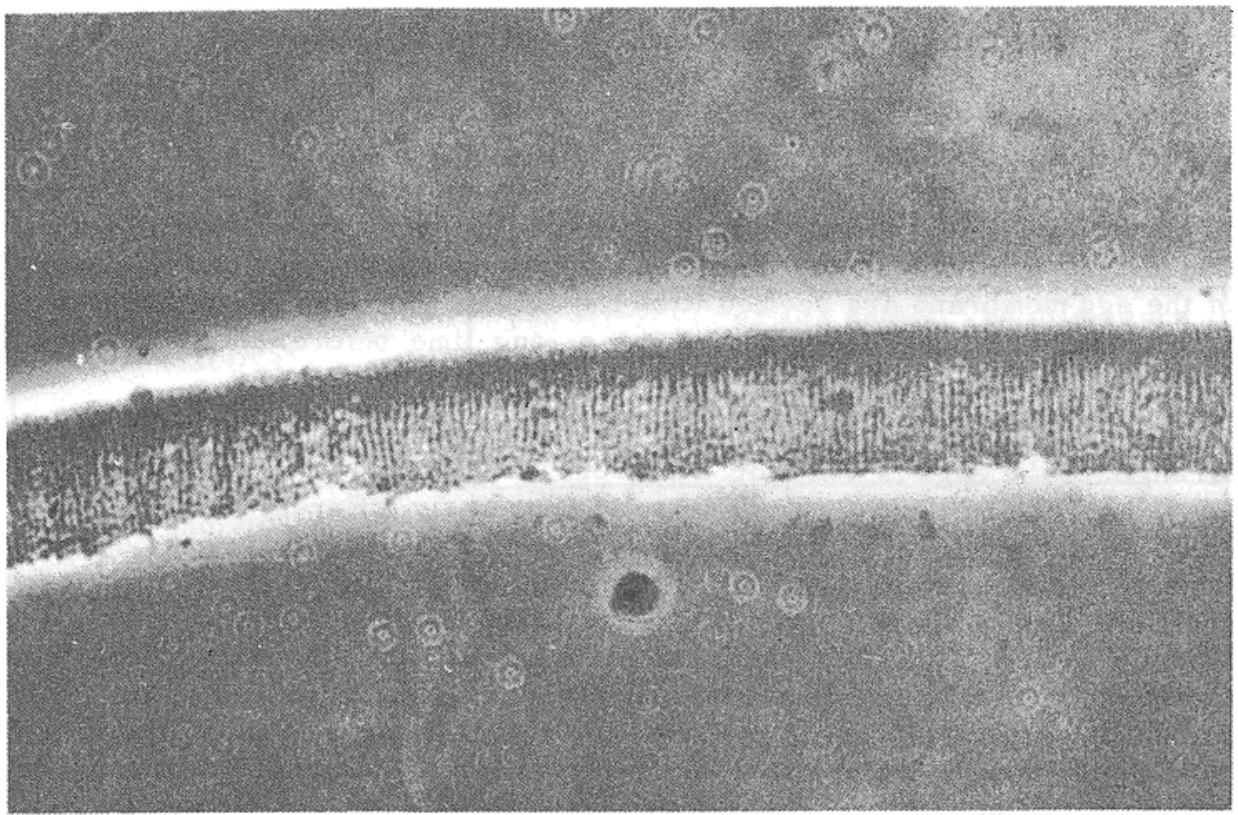

Fig.5. The egg membrane after hatching of larvae 


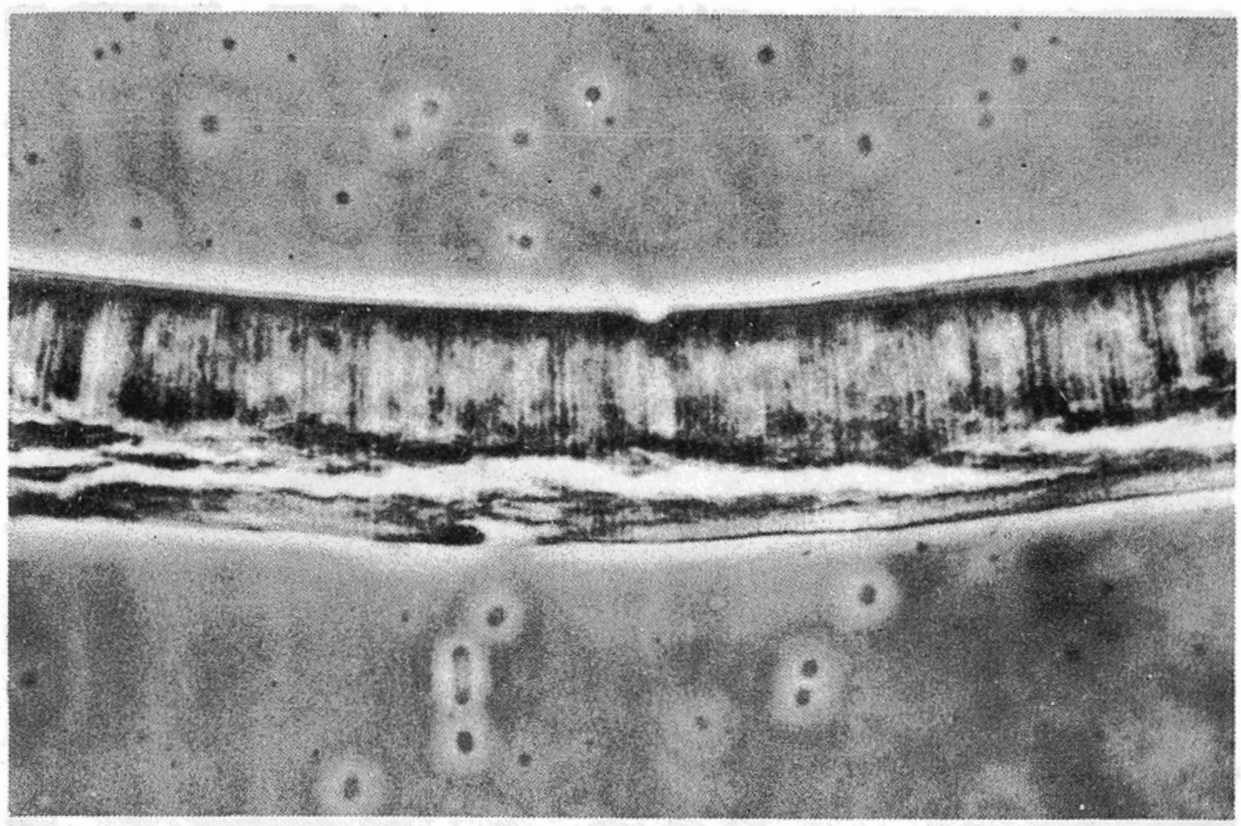

Fig.6. Loosen part of the egg membrane after the action of hatching enzyme

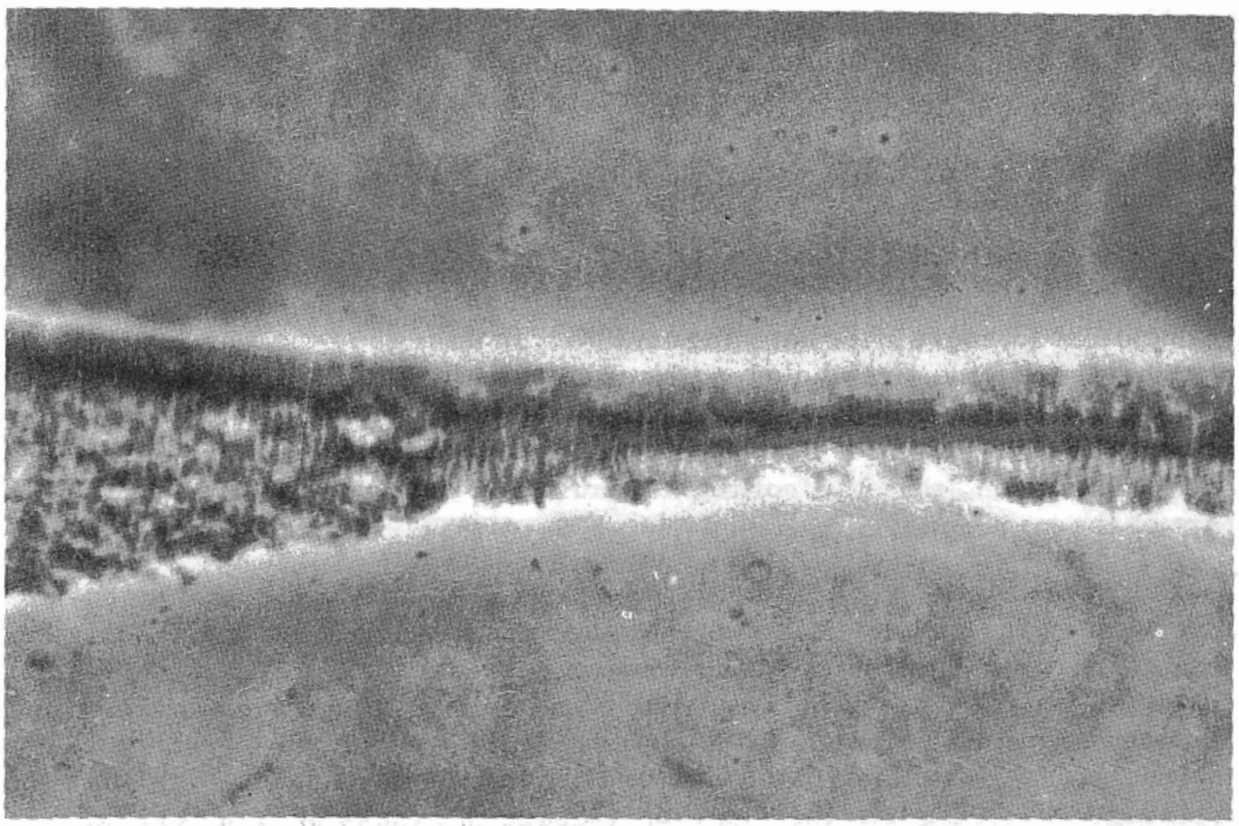

Fig.7. The place of destroying of the membrane (nearby the narrowing) 


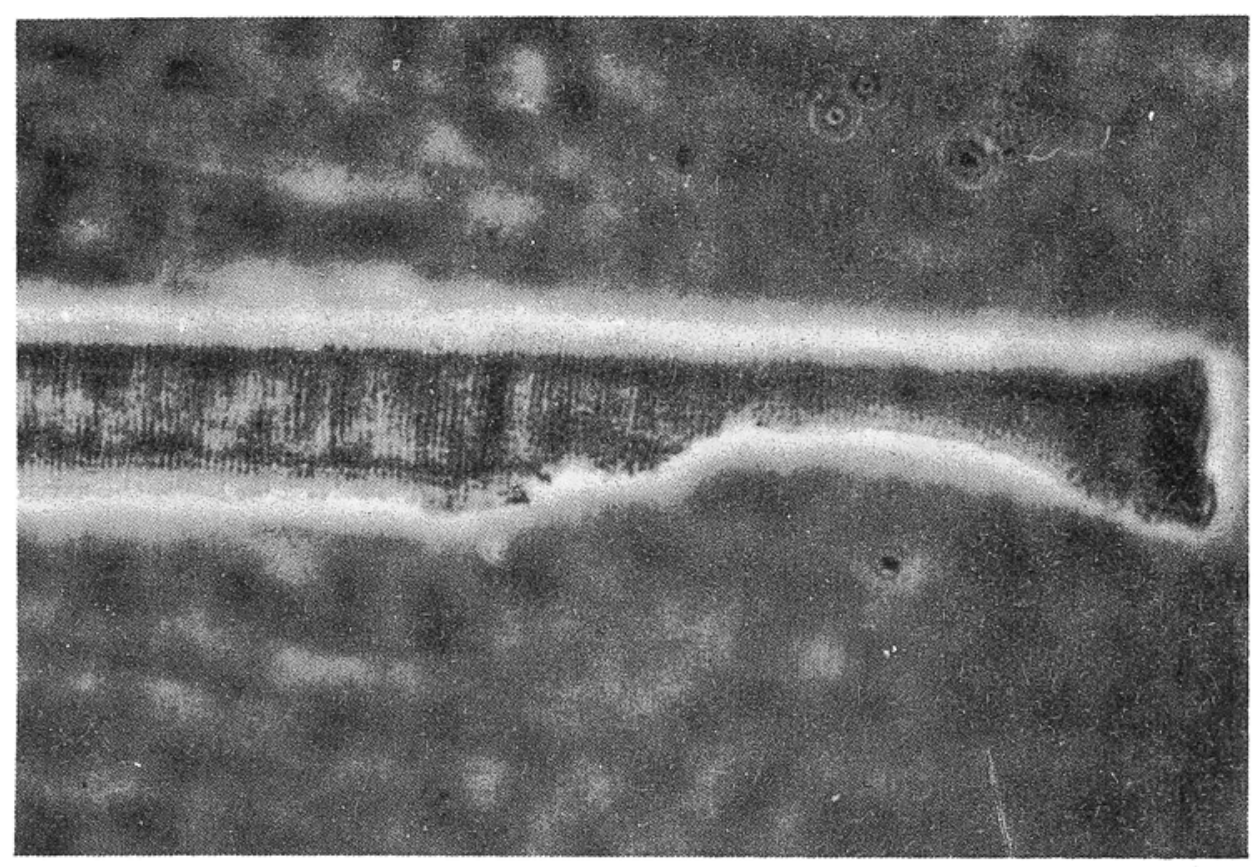

Fig.8. The typical show of breaking place of the membrane

hatching, absolutely opposite fact can be observed: the shell breaks in the thinnest part (of course, the breaking of the breaking of the shell takes place in the parts, which were slightly destructed from the inside).

Thickness measurements of the egg shells from which larval fishes already hatched showed, that generally the shell keeps its normal structure for a few hours (up to $8 \mathrm{hrs}$ at $10^{\circ} \mathrm{C}$ ) and then is gradually destroyed from the inside.

Fig.9 shows the section of the egg membrane in the final state of the decomposition ( 8 hours after hatching at $10^{\circ} \mathrm{C}$ ). In this case, the membrane has been destroyed upon its whole length and from the inside. The characteristic, ring-like rolled end of the section indicates, other, things the above statement to be right, and indicates also, that the external part of the membrane has been less loosen, thus the rolling is caused by the swelling of the internal part of the membrane.

Our investigations in the period before hatching did not show any correlation between the strength of the egg membrane and its thickness. In Table 2, data concerning eggs, however show a great differences in pression strength, nevertheless, do not give any reason for concluding about such correlation. There are cases when eggs with none strength have the shell with average thickness of $38 \mu$ (Table 2, egg number 11); on the other hand the egg showing a strength of $4700 \mathrm{~g}$ has the shell of average thickness of $34 \mu$ (egg No 2). Similarly, the thickness of the egg shell does not correlate with its size. The eggs, as it is shown in Table 2, were generally of the same size (the dif- 
which were not destructed by the hatching enzyme and were placed at a distance of the site of breaking. Calculation showed, that in some cases, the strength reached (in terms on the whole membrane) $6233 \mathrm{~g}(!)$, and thus was equal to the maximal strength of eggmembranes during the whole period of embryonic development.

\section{DISCUSSION OF THE RESULTS AND CONCLUSIONS}

The conviction of many authors, that the strength of salmonid egg membranes falls to "zero" in the moment of hatching is not valid, as it showed the obtained results. Evidently, the egg membrane must become weak to be broken, otherwise, the hatching would be impossible. However, such a weakening does not concern the whole egg, but only some (rather small) parts of it. Such a local action of the hatching enzyme upon the egg shell is caused by the characteristic distribution of hatching glands, which in the embryos trout are placed upon the head and upon some parts of the yolk adjoining the head.

Areas of egg shells, which are not under the action of hatching enzyme do not change their structural and mechanical properties (that is the strength, turgor and elasticity dependent upon the last one (W i n n i c k i, 1967).

In view of the above, it might be presumed, that hatching enzyme produced in hatching glands does not dissolve in perivitelline liquid, but by the direct contact of the glands with the membrane is, in a way "squashed" upon it. The above suggestion would confirm the hypothesis of $\mathrm{H}$ a y e s (1942), that hatching enzyme acts upon the egg membrane only in the medium with definite $\mathrm{pH}$, while in $\mathrm{pH}$ characteristic for perivitelline liquid it is inactive. In the case of direct contact with the membrane the slime from emryo's skin gives the possibility of changing $\mathrm{pH}$ in the place of the enzymatic action.

The character of destruction of the egg shell from the inside, leads into the conclusion that poliprotein micellar structure (F i s he r, 1963) is broken under the action of the enzyme. This is followed by the softening of lower (interior) layers and in consequence - tearing away of the whole slices (Fig.6). Such breaking of course, helps the enzyme to penetrate into deeper parts of the egg membrane.

Local action of the hatching enzyme upon the egg shell involves changes in its mechanical properties, but only in the Flace of the enzymatic action. Beyond this place, the properties of the egg shell remain unchanged. Only after the hatching, the egg membranes are gradually, during a few or even some scores of hours (according to the temperature and number of bacteria present) fully destroyed.

The obtained results showed, that there is no correlation between the thickness of the egg membrane and its strength; it was also showed that the membrane thickness of given species, population, individual or even one egg cannot be expressed in the definite number of microns. Since a great differences were observed in the thickness of egg membranes of one female, and even of individual eggs, only approximate numbers can be given. 
ferences arrived only to 5,3\%) - this compared with the great differences in the thickness (up to 164\%) of the shell excludes any dependence between the two quantities.

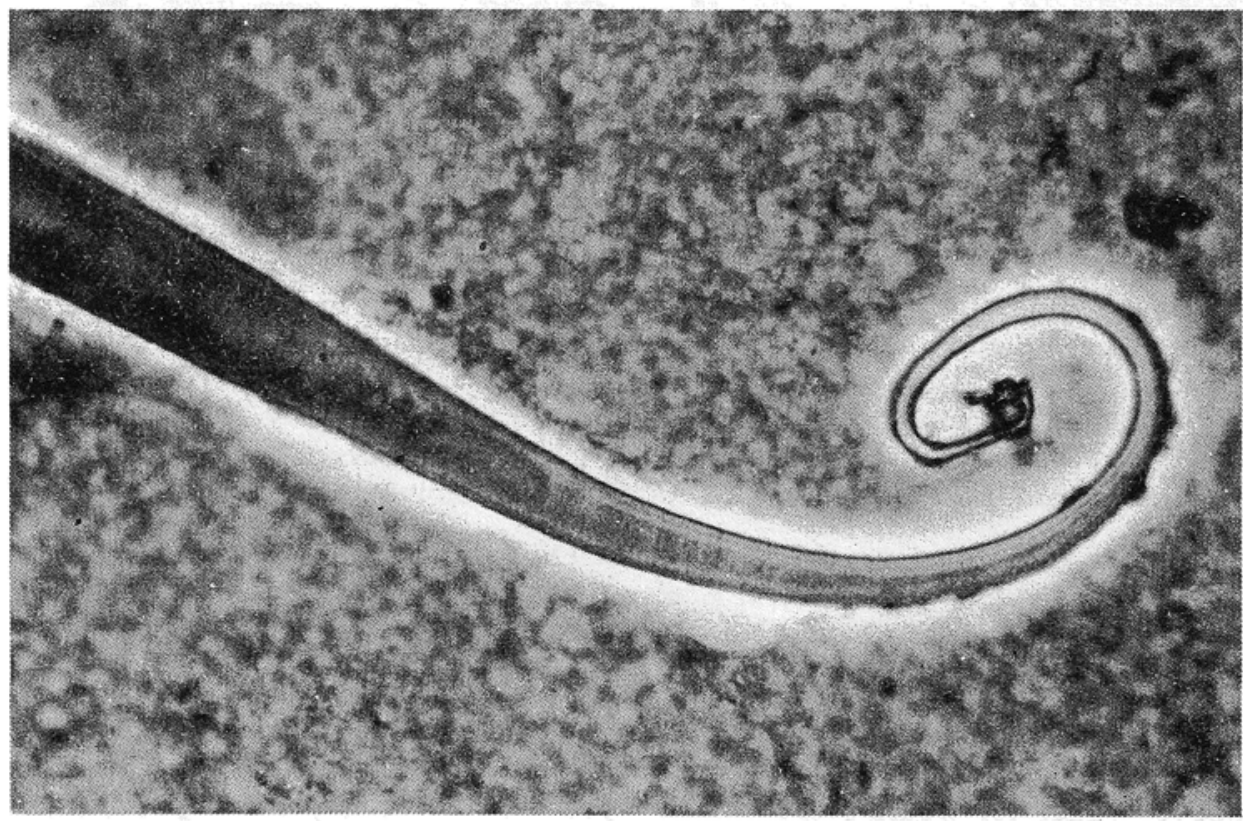

Fig.9. The final state of the decomposition of egg membrane

$\mathrm{T} \mathrm{a} \mathrm{ble}$

The strength of egg membranes, their thickness and dimensions of eggs in the day of hatching

\begin{tabular}{|c|c|c|c|c|c|}
\hline \multirow{2}{*}{ No } & \multirow{2}{*}{$\begin{array}{c}\text { Strength } \\
(\mathrm{g})\end{array}$} & \multirow{2}{*}{$\begin{array}{c}\text { Diameter } \\
\text { of egg }(\mathrm{mm})\end{array}$} & \multicolumn{3}{|l|}{ Thickness of the egg membrane $(\mathrm{u})$} \\
\cline { 4 - 6 } & & maximal & minimal & average \\
\hline 1 & 6500 & 5.39 & 35.00 & 53.75 & 40.48 \\
2 & 4700 & 5.28 & 31.25 & 42.50 & 34.20 \\
3 & 3500 & 5.54 & 35.00 & 52.50 & 41.50 \\
4 & 2700 & 5.32 & 33.75 & 40.00 & 36.74 \\
5 & 1500 & 5.43 & 27.50 & 32.50 & 29.92 \\
6 & 1000 & 5.39 & 21.25 & 38.75 & 32.99 \\
7 & 950 & 5.32 & 35.00 & 47.50 & 39.78 \\
8 & 200 & 5.34 & 27.50 & 36.25 & 32.17 \\
9 & 50 & 5.26 & 37.50 & 56.25 & 46.6 \\
10 & 0 & 5.34 & 33.75 & 49.50 & 37.83 \\
11 & 0 & 5.29 & 35.70 & 43.75 & 38.07 \\
\hline
\end{tabular}

Measurments of the strength of the alone egg membranes after hatching showed, that all shells kept greater strength, of course only in those parts 
Winding up the above, it may be concluded that:

a) Hatching enzyme in the eggs of Salmo gairdneri does not act upon the whole egg shell, but onlyupon its small parts, where hatching glands are in direct contact with the membrane.

b) Decrease of the strength of the egg membrane during hatching is not observed in the whole membrane, but only in the places which were under the direct action of hatching enzyme.

c) In the moment of hatching and just after,the parts of egg shells which were not under the action of the enzyme do not change their structural and mechanical properties.

d) The shells of eggs deriving from the same female are not of the same thickness and in the extreme cases the differences may reach even $162 \%$.

e) The shell of the same egg is not all over of the same thickness. The differences in its thickness in several cases vere over $80 \%$.

f) There is no correlation between the thickness of the egg membranes and their strength (in the eggs of the same female).

\section{REFERENCES}

A rmstrong B.P., C hild J.S., 1965: Stages in the normal development of Fundulus heteroclitus. - Biol. Bull. 128: 143-168.

B a burina E.A., B u znikov G.A., 1957: Żelezy vyluplenija embrionov kubanskogo rybca kak istočnik gialuronidazy i fermenta vyluplenija. Dokl. A.N.SSSR 113: 1387-1390.

B o u r d i n J., 1926a: Le mécanisme de l'éclosion chez les Téléostéens. I.Etude biologique et anatomique. - C.r.Soc.Biol.95: 1149-1151.

B o u r d i n J., 1926b: Le mécanisme de l'éclosion chez les Téléostéens. II. Evolution histologique des cellules séreuses cutanées provoquant l'éclosion chez la Truite. - C.r.Soc. Biol. 95: 1183-1186.

B o u r d i n J., 1926c: Le mécanisme de 1'éclosion chez les Téléostéens. III. Morphologie et répartition des glandes séra uses du tégument. - C. r.Soc. Biol. 95: 1239-1241.

B o u r d i n J., 1926d: Le mécanisme de l'éclosion chez les Téléostéens. IV. Physiologie du liquide périvitellin des oeufs de Téléostéens à l'éclosion. - C.r. Soc. Biol. 95: 1242-1243.

B u z n ik ov G.A., 1957: K fizjologii želez vyluplenija embrionov kostistych ryb. - Ż.obščej Biol. 18: 350-359.

$\mathrm{B} \mathrm{u} \mathrm{z} \mathrm{n} \mathrm{i} \mathrm{k} \mathrm{ov} \mathrm{G.A.,} \mathrm{1959:} \mathrm{O} \mathrm{funkcjonalnom} \mathrm{značenii} \mathrm{gialuronidazy} \mathrm{v}$ ikre kostistych ryb. - Dokl. A.N.SSSR 125: 1382-1385. 
F is he r K.C., 1963: The formation and properties of the external membrane of the trout eggs. Trans.Royal Soc.Canada, I, Ser.IV, Sec.III: 323-332.

Gottwal d St. i. N a g i ęć C., 1967: Rozwój zarodkowyi przebieg wykluwania się stynki (Osmerus eperlanus L.). - Roczn. Nauk Rol.Ser.H, 90,1: 59-79.

Gray J., 1932: The osmotic properties of the eggs of the trout (Salmo fario). - Jurn. Exp. Biol. 9: 277-299.

H a y e s F.R., 1942: The hatching mechanism of salmon eggs. - Exptl. Zool. 89: 357-373.

H e in W., 1908: Einige Versuche über den Einfluss mechanischer Strörungen auf die Entwicklung der Bachforelleneier. Stuttgart. Berichte a.d. Kgl.Baer.Biol. Versuchsstation, 1.

I g n a t e va G.M., 1956a: O nekotorychuslovijach vyluplenija zarodyšej ostrovych ryb. - Dokl. AN SSSR. 109: 1222-1225.

I g n a t e va G.M., 1956b: Ferment vyluplenija u zarodyšej osetrovych ryb i uslovija jego vydelenija:. - Tr.Sovješč. po Fizjol. Ryb. 8: 410 -420 .

I s hid a J., 1944: Further studies on the hatching enzyme of the fresh-water fish, Oryzias latipes. - Annot.Zool.Jap. 22 : 153-164.

K a i g h n M.E., 1964: A biochemical study of the hatching process in Fundulus heteroclitus. - Devl. Biol. 19:56-80.

Milkman R., W o od B.F., Philpott D.E., 1961: Digestion of the Fundulus chorin by the hatching enzyme. - Biol. Bull., 121 397-398.

M ül l e r H., St e r b a E., 1963: Elektronenmikroskopische Untersuchungen über Bildung und Struktur der Eihüllen bei Knochenfischen. II. Die Eihüllen jüngerer und älterer Oozyten von Cynolebias bellotti Steidachner (Cyprinodontidae). - Zool.Jahrb. Abt.Anat. Ontog. Tiere. Dtsch. 8: 469-488.

R ü n n s t r e m J.,1920: Über osmotischen Druck und Eimembranfunction bei den Lachsfischen. - Acta Zool. 1: 321-336.

S c h äpercla u s W., 1940: Untersuchungen an Eiern und Brut von Maränen, Hechten und Forellen. - Verhandl.d.Internat. Verein f theoretische $u$. augewandte Limnologie 9: 215-251.

S ha nkli n D.R., 1959: Studies on the Fundulus chorion. - Journ. Cell. Compar. Physiol. 3: 1-11.

W i $\mathrm{n} \mathrm{n} \mathrm{i} \mathrm{c} \mathrm{k} \mathrm{i} \mathrm{A.,} \mathrm{1967:} \mathrm{The} \mathrm{turgor} \mathrm{of} \mathrm{the} \mathrm{salmonid} \mathrm{fish} \mathrm{eggs} \mathrm{during} \mathrm{hatching.}$ - Bull.Acad.Pol.Sci. 25 (15) , 12: 785-787.

W i n n i c k i A., D o m u r a t J., 1964: Wytrzymałość osłonek jajowych niektórych ryb rozwijających się w różnych środowiskach. - Zesz.nauk. WSR Olszt. 18: 315-324. 
W i n t ré be r t P., 1912: Le mécanisme de l'éclosion chez la truite arc-en-ciel. - C.r.Soc.Biol. 72: 724-727.

W i n t r ébe r t P., 1926: L'éclosion de la Perche (Perca fluviatilis). - C.r.Soc.Biol. 95: 1146-1148.

Z ot in A.I., 1953a: Načalnyje stadii processa zatverdevanija oboloček jaic lososevych ryb. - Dokl. AN SSSR 89: 573-576.

Z ot in A.I., 1953b: Ferment vyluplenija u zarodyšej osetrovych ryb. - Dokl. AN SSSR 92: 685-687.

\section{STRUKTURALNE I MECHANICZNE ZMIANY ZACHODZĄCE W OSEONKACH JAJOWYCH PSTRĄGA TĘCZOWEGO \\ (Salmo gairdneri Rich.) \\ W OKRESIE WYKLUWANIA SIE LARW}

\section{Streszczenie}

U jaj pstrąga tęczowego (Salmo gairdneri Rich.) badano morfologiczne i mechaniczne właściwości osłonek w okresie bezpośrednio poprzedzającym wylęg w momencie wyklucia oraz w okresie tuż po wykluciu się larw.

Stwierdzono, że ferment wyklucia nie oddziaływuje na całą osłonkę, lecz tylko na niewielkie jej partie w miejscach,gdzie gruczoły wyklucia wchodzą w bezpośredni kontakt z osłonką. Podobnie i proces spadku wytrzymałości osłonki w okresie wykluwania się larw nie dotyczy całości osłonki, lecz jedynie miejsc, które były poddane bezpośredniemu działaniu fermentu wyklucia.

W momencie wykluwania się larw jak również tuż po wylęgu osłonka nie dotknięta działaniem fermentu wyklucia zachowuje w niezmiennym stanie zarówno swą strukturę jak i swe właściwości mechaniczne.

Osłonki larw tej samej samicy nie są jednakowo grube i różnice w skrajnych przypadkach sięgają $160 \mathrm{i}$ więcej procent. To samo dotyczy osłonki pojedynczego jaja, aczkolwiek w mniejszym stopniu i maksymalne różnice w grubości dochodzą do $80 \%$.

Nie stwierdzono żadnej korelacji między grubością osłonek a ich wytrzymałością w obrębie jaj tej samej samicy. 
СТРУКТУРНЫЕ И МЕХАНИЧЕСКИЕ ИЗМЕНЕНИЯ В ЯЙЦЕВЫХ ОБОЛОЧКАХ

РАДУЖНОЙ ФОРЕЛИ (SALIO GAIRDNERI RICH.) В ПЕРИ ОД ВЫКЛЁВА ЛИЧИНОК

$$
P \text { e } 3 \text { r } M \text { e }
$$

Изучали морфоологические и механичесіие свойства яйцевых оболочек радужной форорели перед выклёвом, во время выклёва а также непосредственно после выхода личинок из яиц.

Установили, что ф̆ермент вылупления не действует на всю оболочку но только лишь на небольшие её участки в местах, где железы вылупления вступают в непосредственный контакт с оболочкой. Точно также и процесс падения прочности оболочки в период выклёва личинок не захватывает всю оболочку, только те её участки, которые находятся под непосредственным воздействием фермента вылупления.

В момент выклёва личинок, а также сразу после выклёва, яйцевая оболочка не тронута воздействием фермента вылупления сохраняет в неизменном состоянии как структуру так и свои механические свойства.

Оболочки яиц той же самой самки не одинаковы. по толщине и разницы в. толщине в экстремальных случаях достигают 160\% и больше. То же самое касается оболочки отдельного яйца, хотя в меньшей степени, и максимальная разница в толщине разных её участков достигает 80\%.

Не нашли никакой кореляции между толщиной оболочек и их прочностью среди яиц происходящих от одной самки.

Àddress :

Doc.dr habil.Aleksander Winnicki

Katedra Ichtiologii WSR

Szczecin, ul. Kazimierza Królewicza 4

Polska - Poland

Received 28.IV.1969 